\title{
WHAT DO WE CALL THE CHILDREN? FAMILIAL TERMS OF ADDRESS IN POLISH AND ENGLISH
}

Keywords: terms of address, children, cultural scripts, individualism, collectivism, teaching Polish as a foreign language

\begin{abstract}
The paper addresses cultural differences between Polish and English as they pertain to familial terms of address. Using corpus data, I demonstrate that Polish parents frequently address their children using hypocoristic forms of the terms syn 'son', córka 'daughter' and dziecko 'child'. These forms convey affection and emphasize familial ties. English parents, on the other hand, use children's names, nicknames, or terms of endearment. I argue that these differences follow from underlying contrasts in cultural scripts: English individualism and Polish warmth.
\end{abstract}

\section{CULTURAL VALUES}

Culture is often called the fifth skill in foreign language teaching (in addition to speaking, listening comprehension, reading and writing). This is especially true when the target culture is of a different type to the native culture of the learners. Cultures have been classified in various ways: individualistic vs. interdependent/collectivist, high context vs. low context (Hall 1976), etc. These differences are conveyed in a multitude of different ways in speech, body language, facial expressions, etc. This paper addresses cross-cultural differences in Polish (a culture typically classified as interdependent and high context) and English (individualistic) use of familial forms of address, that is, kinship terms (mother, father) and kinship diminutives or hypocoristic forms (mom, daddy). The data discussed in the paper comes from the Polish National Corpus (NKJP), the British National Corpus (BNC), and the Corpus of Contemporary American English (COCA).

*dziwirek@uw.edu, University of Washington, Department of Slavic Languages and Literatures, box 354335, Seattle, WA 98125. 
I argue that at the root of some key lexical gaps in English and the differences in familial forms of address in the two languages are contrasting values underlying each culture. Namely, "uniqueness/individuality" in English and "warmth" in Polish (and more broadly Slavic). The latter has been formulated by Wierzbicka (1999) as follows:

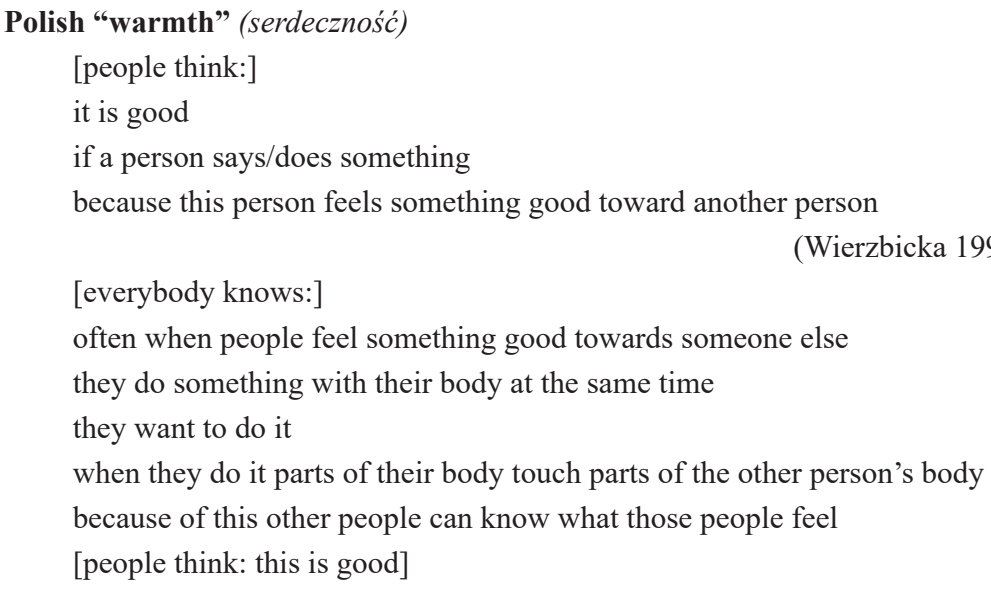

(Wierzbicka 1999, pp. 253-254)

The explications in (1) state that in Polish culture expression of positive emotions towards others is "good", something that should be communicated with both words and bodily actions. As Wierzbicka says:

What is "good" (from a Polish cultural point of view) is a spontaneous manifestation of "good feelings" towards another person (i.e. of interpersonal "warmth", "serdeczność") Wierzbicka (1999, p. 253)

That the English speaking people place a high value on their individuality is very well documented (e.g. Nisbett (2003), Markus and Kitayama (1994)), below is my representation of this value in Wierzbicka's NSM.

\section{(2) English individuality}

[everybody knows:]

I am not like other people

I am me

no person is like me

[people think: this is good]

How are forms of address related to the cultural values in (1) and (2)? Wierzbicka (1992) argues that expressive derivation as applied to personal names demonstrates the high value that Polish speakers place on interpersonal relationships. Her analysis of soft and hard stem short forms and suffixes $-k a$, -ek, -eńka, -eczka, -cia, -uś, -unia/-unio, -ulka/-ulek, -ik, -usik, -ątko, -ch, -cho, -chu, -cha, 
-ucha, -chna, -uchna, and -uśka assigns a unique meaning to each form, but all the explications center on good feelings ("I feel something good toward you").

Wierzbicka (1992, p. 236) also analyzes English family relation terms and groups them into three categories: child-source family terms (Mummy, Daddy, Auntie, Granny), non-childish but intimate (Mum and Dad), and non-childish, non-intimate family terms (Mother and Father). What is striking about the English terms, from the Polish perspective, is the lack of adult-source terms for the children. In other words, English speakers typically do not address their children as "son" or "daughter", while Polish speakers do so frequently.

This striking lexical gap in English as compared not only to Polish but to all of the Slavic languages, Romance languages, several Germanic languages, and in fact most of the languages of the world, is what this paper is about.

In the rest of the paper I discuss the Polish hypocoristic forms based on córka 'daughter', syn 'son', and dziecko 'child'. I focus on their meanings, frequencies, and the fact that they exhibit both archaic and innovative morphological properties. I discuss the corresponding English forms and come back to cultural values as an explanation at the end.

\section{DAUGHTERS}

The basic word for daughter in Polish is córka, whose vocative córko occurs 193 times in the Polish National Corpus (NKJP) ${ }^{1}$. A brief note on my material gathering methodology here: in informal speech both the vocative and the nominative can be used as forms of address in Polish, e.g. Marysiu/Marysia, mamo/ mama, Jurku/Jurek, etc. For the purposes of this paper I focus only on the vocatives, as they are, for the most part, used uniquely as forms of address, and thus are clear examples of speaking to rather than about children.

The basic form córka is non-childish and non-intimate and does not seem to convey either positive or negative emotions, it is a form that could be used in addressing small children, but most likely would be directed at older children or adults.

(3) Mało ze sobą rozmawiamy, córko. Mało. Jestem taki zajęty. Tyle mam pracy.

We talk too little, daughter. Too little. I am so busy. I have so much work.

The most frequent hypocoristic form of córka is córeczka, whose vocative form córeczko is found in the NKJP 284 times. It can be used towards young children and adults.

${ }^{1}$ Córka is morphologically a diminutive. The form córa, does still exist vestigially in Polish, but córka is the neutral term for daughter. 
(4) Martuniu, mnie też jest ciężko. Daj mi, córeczko, jeszcze jedne piwo z lodówki.

Martha-dim, things are also hard for me. Give me, córeczko, one more beer from the fridge.

According to Wierzbicka (1992, p. 278), who discusses it when it is added to personal names, the suffix -eczka means:

(5) - -eczka

I feel something good toward you of the kind that people feel toward children (e.g. Haneczka)

Wierzbicka (1992, p. 278)

This seems to fit córeczka perfectly, since the concept of a child is at the root of the meaning of daughter, but is more problematic when we consider another frequent family term, namely, cioteczka 'auntie' from ciotka 'aunt'. Since an aunt is prototypically an adult (though there can be children who are aunts), I would suggest that the definition of -eczka be amended to include the following statement:

(6) $-e c z k a$

I feel something good toward you

of the kind that people feel toward children (e.g. córeczka)

or that children feel toward people and things they feel something good toward

(e.g. cioteczka)

This would also account for the fact that many of the common nouns in -eczka have a distinctly child-sourced/-directed feel: buteczka "lit. little bun", chusteczka 'lit. little handkerchief", buteleczka "lit. little bottle", bajeczka "lit. little fairy tale", etc.

The next form in terms of frequency in NKJP is córuś (72 times), illustrated in (7).

(7) Rozpakowałaś się, córuś? - zapytała mama, stawiając w pokoju dwie siaty.

Did you unpack, córuś? - asked mom, putting down two bags.

Córuś is a most curious word, as the suffix - uś is typically found with masculine stems, mostly personal names (e.g. Wojtuś, Jacuś), but also tatuś from tata 'daddy', synuś from syn "son" and dziadzius' from dziadek "grandfather". In fact, córuś 'sweet daughter', matuś (29 examples in NKJP) 'mommy', mamuś (122) 'mommy', and babus' (3) 'grannie' are the only feminine common noun examples.

Since -uś in córuś and matuś/mamuś does not ascribe any masculine properties to mother, daughter or grandma, and it does not trigger masculine agreement (moja córuś), it is most likely not the same suffix found in the -uś masculine nouns ( $W o j-$ tuś, tatuś), especially since Polish (unlike Russian) names and forms of address are sex-differentiated and there are no unisex suffixes (Wierzbicka 1992, p. 270). 
In some ways this form resembles the Russian truncated vocative or neo-vocative (this is what Anstatt (2003) suggests). In Russian, the old Slavic vocative has been lost except for a few frozen forms, but a new vocative form has arisen since the mid-19 ${ }^{\text {th }}$ century (Parrott 2010, p. 212) for names and kinship terms ending in $-a$. In those forms the final $-a$ is omitted, e.g. mam from mama, Tan' from Tan 'a, Saš from Saša (Parrott 2010, p. 212), though final syllables can be truncated as well: ma (from mama), pa (from papa), ba (from babuška 'granny'). In Russian this appears to be quite productive, though phonologically restricted to those forms which have a penultimately stressed nominative (Parrott 2010, p. 212).

Truncation of terms of address is not limited to Russian, but appears to be a common cross-linguistic phenomenon. Yokoyama (1994) proposed that truncation can be viewed as an iconic representation of shortening of interlocutor distance. Yokoyama cites Greek, Baltic and Indonesian as languages which use it as a mechanism to create more familiar terms of address. We do not need to look further than the English ma, pa, sis, unc, bro, Pat, Chris, etc., to see this tendency at work.

It is true that shortening the form of address is an indication of shorter interlocutor distance and closer relationships. In English, Bob is closer to us than Robert and Robert is closer than Mr. Templeton. But this is not the whole story. This is the case when we speak to adults. When we speak to children, typically, the longer the form is, the more affectionate it is: English Bobby is more likely to be used toward a small child than Bob, Polish syn 'son' is less affectionate than synek, which is less affectionate than syneczek. The more diminutive suffixes you pile up, the more closeness you convey. Given that one of the key functions of diminutives is to indicate a small size, I would argue that the fact that diminutives are prototypically used in child-directed speech arises from the universal human propensity/desire to make the world smaller, friendlier and more bearable for our children. We want our children to believe that their world is cozy and safe, using whatever resources our languages have.

English does not have too many diminutives, yet the ones it does have have not gone out of style for generations. Parents in 2019 still use words like doggie to make dogs less threatening, blankie to make a blanket more inviting, auntie Sue to make aunt Sue more appealing, etc. These forms are typically longer than their base forms (dog, aunt) and sound softer in some not easily definable way (blankie vs. blanket).

So it seems to me that Yokoyama's model of iconic interlocutor distance needs to be amended to allow for child-directed speech and diminutives which convey greater closeness, and yet lengthen rather than shorten terms and forms of address. I would argue that child-directed terms tend to be longer and softer and express more affection and warmth, by making the common objects sound smaller, softer and sweeter. In Polish, calling someone Asia rather than Joanna 
definitely shortens the interlocutor distance among adults, but parents would most likely call their Joanna Asieńka rather than Asia to convey more closeness and love. Eating a kotlecik rather than a kotlet 'cutlet' or buteczka rather than butka 'bun' sounds much more appealing and manageable.

This brings us back to córuś, which conveys both the softness inherent in córusia and the familiarity found in English sis or unc. It is an anomaly given all

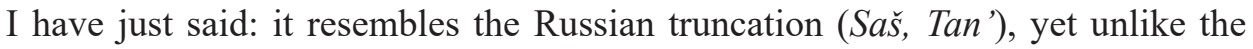
Russian neo-vocative it is not new, it sounds distinctly archaic and old-fashioned. According to Szymczak (1966) the forms matuś and córuś have been attested since Middle Polish (Maryś is found in Jan Kochanowski's (1530-1584) poetry). Also unlike the truncation trend in Russian and English, in Polish this phenomenon is restricted to a single suffix (-usia $\rightarrow-u s$ ).

Following Zalewski's (1963, p. 288) suggestion, I would like to claim that, given their limited scope, the feminine forms of address in -uś (córuś, matuś, mamuś, babuś plus several personal names) are driven/triggered by analogy with familial terms like tatuś 'daddy', synuś 'lit. little son', dziadziuś 'grandpa', rather than the general cross-linguistic truncation-as-closeness trend.

The vocative córciu from córcia occurs in the NKJP 33 times. The suffix -cia is characterized by Wierzbicka (1992) as "affectionate and patronizing" (278) and when added to names is typically used by mothers and aunts, not by romantic partners. It is cheerful and playful but can be interpreted as patronizing (279).

(8) Ewo! Moja córciu miła! Wrócę późno, a więc sama zabierz się do gotowania.

Ewa-voc. My dear córciu. I will be late back, so you get started on the cooking.

Córeńka is perhaps the most affectionate form of córka. It occurs in NKJP 17 times. Wierzbicka characterizes the meaning of -eńka as not only containing the regular affection component ("I feel something good toward you"), but also an additional loving component ("I feel something good speaking to you.")

(9) Tylko ubierz się ciepło, córeńko. Noc ma być pogodna i mroźna.

Make sure you get dressed warmly, córeńko. The night is supposed to be clear and frosty.

There are several other forms of córka which can be used as form of address: córunia (15 examples of voc. córuniu in NKJP), córuchna (12 examples of voc. córuchno), córusia (voc. córusiu, 1 example in NKJP), córulka (jocular, not used as a form of address). Szymczak (1966, p. 42) also lists córuńka, but neither córuńka nor the vocative córuńko occurs in the NKJP.

To summarize, there are 8 common forms of córka 'daughter', which are attested in the NKJP in the vocative and which provide evidence that Poles frequently address their daughters using hypocoristic forms of this familial term. Their meanings vary from affectionate, to very affectionate, to jocular, pitying, patronizing, etc. In contrast, English has no diminutive form of daughter and it is highly unlikely that English speakers address their daughters as "daughter" or "my dau- 
ghter". The Corpus of Contemporary American English (COCA) contains 7,293 occurrences of "my daughter" perusals of about 1000 tokens yielded no appellative uses.

\section{SONS}

Turning to sons, the basic Polish word is syn. Its vocative form synu occurs in the NKJP 1,531 times. Looking at the collocation clusters, we can eliminate about 500 locative uses (with which the vocative is syncretic), about 80 where the word is used in a prayer addressing Jesus (e.g. Jezu, synu Boży 'Jesus-voc., son-voc. God-gen'), and about 20 curses (e.g. psi synu 'dog-gen son-voc., i.e. son of the dog', diabli synu 'devil's son-voc., i.e. son of the devil'). There are also a number of examples, where synu is used by a priest to address a penitent or parishioner. This leaves approximately 900 vocative uses addressed to a male offspring. It is typically not used toward little boys. Used to address a small child it sounds as if the parent were trying to tell the boy to "man up", be brave, be daring.

(10) Nie przejmuj się, synu. Wiesz, że zawsze byłem pobłażliwy.

Don't worry, synu. You know that I have always been lenient..

The form synku is found in NKJP 692 times. Of these 11 are locative uses found after prepositions $o, p r z y$ and $w$. The level of affection expressed here is somewhere between that of córko and córeczko. Addressing someone as córko is much softer than synu since córka is a morphological and historical diminutive. As a result, synku sounds more affectionate than córko (which corresponds to synu in terms of order of derivation), but not as loving as córeczko since the morphological equivalent of córeczka is syneczek.

(11) Brawo, synku! - Rzuciłem się w stronę Franka, który uśmiechając się od ucha do ucha, wracał do swojej zwykłej kolorystyki.

Bravo, synku! I hurried towards Frank who, grinning from ear to ear, was returning to his natural color.

Syneczek is a diminutive formed from synek, and thus a more affectionate form. Its vocative syneczku is found in NKJP 88 times. Its meaning is comparable to córeczka though perhaps a little more loving and small-children-directed, since there is a three step word formation here (syn-synek-syneczek) vs. a two-step derivation of córka-córeczka.

(12) Powiedz, syneczku, co będziesz robił, gdy będziesz duży?

Tell me, syneczku, what will you do when you grow up? 
All of the occurrences of syneczku in NKJP are vocative, even though, this form (like synku) is syncretic with the locative. This is indicative of the fact that even more than its feminine counterpart -eczka, -eczek is a very affectionate affix, characteristic of family or in-group speech, especially when added to names or family terms (e.g. Jureczek 'Georgie' from Jurek/Jerzy, wujeczek from wujek 'uncle'). When added to common nouns, it is used primarily in child-directed speech (czlowieczek 'little person', domeczek 'little sweet house', jasieczek 'little small pillow', ganeczek 'little inviting porch') meaning roughly "very sweet, non-threatening, small and lovely thing or person". When it is attached to a familial term or a name, it is used primarily as a form of address. If a parent were to talk about the fact that they think about their son (o syneczku) or sit by their son (przy sy$n e c z k u$ ) using this form, they would sound soppy, overly sentimental or maudlin.

In contrast, the form córeczce (locative and dative of córeczka) is found in NKJP 146 times, showing that parents are more likely to speak about their daughters using this term than they are willing to speak about their sons using syneczek. One reason is the fact that córeczka is not quite as affectionate as syneczek due to it being the second order diminutive and thus more appropriate for discourse outside of the family, but gender norms are most likely another: it is more acceptable to talk about a daughter as a sweet, small, cuddly being in public than it is to talk that way about a son.

The form synuś is not exactly parallel to córuś as -uś is the expected masculine diminutive suffix (e.g. tatuś 'daddy', dziadziuś 'grandpa', Jacuś). It occurs in NKJP 81 times, 32 of which are direct address uses.

(13) No i cóż mu poradzisz, synuś? Ani jemu nie pomożesz, ani jego rodzinie And what will you tell him, synuś? You cannot help him or his family.

Wierzbicka (1992) says that forms in -uś "evoke lovable delightful small creatures" and defines the meaning of -uś personal names as follows:

Forms in -usia or -uś (e.g. Martusia, Wojtuś)

I feel something good toward you

of the kind that people feel toward children

I imagine that looking at you, people feel something good

(Wierzbicka 1992, p. 281)

I think that Wierzbicka's definition is right, even though most of the uses of vocative synuś in NKJP seem to be addressed to adult sons, where the "lovable, delightful, small creatures" image usually does not apply. But the definition is formulated in a way that applies to synuś too. Parents looking at their adult son, could feel something good: nostalgia for the small child he had been, pride or pity in how he turned out. It seems to me to be a compromise form: soft and affectionate but not as child-oriented as syneczek and thus often used toward adult sons. 
The vocative of synuś, synusiu occurs in NKJP 5 times ( 5 uses are locative). Examples show that it can be addressed to both small and adult sons.

(15) Proszę się oduczyć takiego rzucania śliniaka. Nie ma w ogóle mowy, żebyś tak robił.

Oj mój ty synusiu kochany! Najpiękniejszy na świecie!

Please stop throwing the bib, it is unacceptable! Oh, my beloved, most beautiful synusiu!

In addition to the 5 appellatively used forms of syn discussed above there are several others: synunio (voc. synuniu), syneniek (voc. syneńku), syncio (voc. synciu), and synulek (voc. synulku). Szymczak (1966, p. 38) also lists the less common synczek, synaczek, synuchna, szynuszek, synuleczek, and synkcio. Thus, as in the case of daughters, Polish parents of sons have plenty of hypocoristic forms based on the root syn to address their offspring ${ }^{2}$.

English speakers use son as a form of address much more frequently than daughter (which is not really saying much). When son is used towards the speaker's child it is often in the context of giving manly advice, as in the following examples from the Corpus of Contemporary American English.

(16) ... and sent him back to school with the words, "Remember, son, for them it is a fight, for you it is life and death."

The BNC provides other examples which seem to be addressed to the speaker's child:

(17) 'Well, son, how about it?' he asked, giving Philip the tray.

But in English, son is most often used as a form of address by older men in a position of authority towards younger men who are not their children (and who in turn would tend to address the older men as sir). This can occur in hierarchically structured groups such as the military. It can also be a patronizing put down, and has been used as such in the US by white men towards black men, no matter their respective ages.

The Corpus of Contemporary American English lists 2,707 occurrences of sonny (out of 425 million words). The BNC lists only 210 (out of 100 million words), and of the 50 examples provided, the vast majority are uses of Sonny as first name or nickname (spelled with a capital S): Sonny Rollins, Sonny Ramphal, Sonny Bono, etc. Sonny frequently co-occurs with boy (95 times in COCA), and can be used towards one's own children, as in (18), but also toward people who are not as in (19), while others are ambiguous without the context (20). It can also sound patronizing.

(18) Sonny boy, can your father give you a piece of his personal advice?

${ }^{2}$ Synalek is a jocular form that is typically not used as a form of address, but can be used about a son who is perhaps being naughty or acting as a smarty-pants. 
(19) ... Jack Kennedy's ambition to be President. Behind his back Johnson called him "sonny boy", sneered at his meager accomplishments in the House and Senate.

(20) I couldn't even budge it. "You practice lifting that, sonny boy, and you'll become Charles Atlas" he laughed.

To summarize the discussion of son and daughter as familial terms of address: Polish has 8 common hypocoristic forms based on córka and 9 such forms based on syn. There is a gender difference: some of the diminutives of syn are used primarily as forms of address, as they are considered too intimate to be used in discourse about one's sons. English has no hypocoristic forms of daughter and English speakers tend not to use daughter as an address form (apart from religious contexts). We do find examples of English son, sonny and sonny boy as forms of address, but they are often directed at other people's children and can be patronizing and condescending. Most speakers of English address their children by their names, nicknames, or terms of endearment.

\section{CHILDREN}

Polish parents also frequently use dziecko 'child'. It is not possible to estimate the rate of the occurrence of dziecko as a form of address since the nominative and vocative (as well as the accusative) are syncretic and the NKJP reports 30,497 uses of this term, but a perusal of about a 1000 entries yields examples like (21). Dziecko can be used towards adult children though much less frequently than forms of córka and syn, it can also be used towards other people's small (not adult) children.

(21) Biedne dziecko. Za dużo brazylijskich telenowel, za szybko chcesz dorosnąć!

Poor child! You watch too many Brazilian soap operas, you want to grow up too quickly!

Dziecko has several diminutive and hypocoristic forms ${ }^{3}$. Many of them are strongly imbued with compassion as they are often used in Christmas carols about the baby Jesus, who is to be pitied as he is born in the manger among the animals, lying on hay without a pillow, etc. (24) contains examples of dzieciatko, dzieciateczko, dziecię, and dziecineczko from popular Polish carols.

(22) a. Poszli, znaleźli, dzieciątko w żłobie.

They went and they found a child in the manger.

(Wśród nocnej ciszy 'In the quiet of the night')

${ }^{3}$ Dziecko also has some interesting plural forms. The neutral plural is the irregular $d z i e c i$, but there are also dziatwa, dziatki, dzieciarnia, dzieciska all meaning 'children', none having a morphologically corresponding singular. 
(22) b. Przybieżeli do Betlejem pasterze, grają skocznie dzieciąteczku na lirze

To Bethlehem the shepherds came, they play the lyre for the child.

(Przybieżeli do Betlejem “They came to Bethlehem')

c. Podnieś rękę Boże dziecię, błogosław ojczyznę miłą.

Child of God, lift up your hand and bless our beloved fatherland.

(Bóg się rodzi 'God is being born')

d. Witaj dziecineczko w żłobie, Wyznajemy Boga w tobie.

Greetings, little baby in the manger, we recognize the God in you

(Pójdźmy wszyscy do stajenki 'Let's all go to the stable')

Dzieciatko occurs in NKJP 237 times, with few appellative uses. It is mostly found in reference to baby Jesus.

(23) To wszystko ona własnymi rękami robiła, ona, moje dzieciątko kochane!

She did all this with her own hands, she, my dear dzieciatko.

Wierzbicka (1992) notes that the suffix -atko is prototypically used to denote baby animals (e.g. kociatko 'kitten') and characterizes the meaning of the suffix -atko as follows:

(24) Names in -ątko (e.g. Jasiatko, Marysiątko)

I feel something good towards you

of the kind people feel towards baby animals

I feel something good speaking to you

I want to speak to you as if you were a baby animal, not a child

(Wierzbicka 1992, p. 285)

Dzieciateczko is the diminutive formed from dzieciatko and occurs in the NKJP 10 times. Again, mostly with reference to baby Jesus.

(25) Dobrze, dobrze, moje dzieciąteczko kochane.

Well, well my beloved dzieciateczko.

There are 409 instances of dziecie (whose vocative is syncretic with nominative and accusative), though it seems to be used appellatively rather rarely. It has an archaic sense, and is often found in the phrase Boże dziecię 'God's child'.

(26) Patrz dziecię i ucz się na złym przykładzie.

Look, dziecie, and learn from the bad example.

Dziecina contains the suffix -ina, which typically suggests pity, compassion, disregard, or disdain (Pyzik 2000, pp. 312-313), eg. chtopina 'a pitiful man', babina 'a pitiful old lady', mieścina 'tiny, undeveloped town', sukienczyna 'threadbare, meager dress', etc.). Dziecina does suggest pity and compassion and can be slightly patronizing as it foregrounds the frailty of the child. Perhaps for that 
reason it is not often used about baby Jesus (being condescending about the son of God is not appropriate). It is found in the vocative 67 times in NKJP:

(27) Uważaj na siebie, dziecino, jesteś blada. Twój profesor zanadto cię eksploatuje.

Take care of yourself dziecino, you look pale. Your professor is exploiting you too much.

Dziecinka (voc. dziecinko) is a diminutive formed from dziecina and, like syneczek, is a form that occurs primarily in the vocative (61 examples in the NKJP); it is too intimate to use when talking about one's child. It can be used towards adult children, as seen in (28), but is mostly directed at small children and often co-occurs with other diminutives.

(28) Dziecinko, co ci przychodzi do tej główki - roztkliwiła się ciotka Agata.

Dziecinko, what ideas you have, teared up aunt Agata.

The form dziecineczka (voc. dziecineczko), seen in the carol in (22d), is a diminutive of dziecinka and is not found in the NKJP.

Searching for appellative uses of child in English presents similar difficulties (there is no unique vocative form). BNC reports 89 instances of child followed by an exclamation point. Many of them were of the Don't treat me as a child! variety, i.e. examples where child just happened to be at the end of the sentence. But there were also the following examples where child does appear to be used as a form of address, though, not necessarily to one's own child:

(29) a. Dear child, never, never volunteer!

b. My dear child, stop!' she cried in agitation.

Another English word, for child, namely kid, does have a hypocoristic form kiddo. It appears to be more common in American English (345 instances in COCA vs. 7 examples in the BNC). We could almost say that this is a vocative, as an overwhelming majority of examples are appellative.

(30) a. Listen, kiddo, I'm going to get rolling.

b. "Jamie, get a move on, kiddo" he says from the door to the garage.

In summary, there are at least 7 hypocoristic forms based on dziecko "child", which Polish parents frequently use to address their children. In English, child can be used as form of address, but has no diminutive forms, though there is a fairly new near-vocative form kiddo (The OED cites its first use as 1905).

\section{DISCUSSION}

The existence of motherese, a speech register used by adults towards infants and young children, linguistically simplified and characterized by high pitch and exaggerated intonation, has been confirmed by a number of crosslinguistic studies 
(Fernald (1985), Gleitman, et al. (1984), Matychuk (2005)). While many of these studies focus on pitch and other prosodic qualities of child-directed speech, and while there is currently no agreement as to its universality and status as a species-specific adaptation, it is clear that motherese exists in both Polish and English: in both languages parents coo at infants and use diminutives.

What I would argue is different about Polish, is that its child-directed discourse seems to be much richer than the comparable mode of communication in English. What I have focused on here are the child-directed familial terms of address. I have shown that Polish speakers often use the forms of the words son, daughter and child to address their children. These forms convey various shades of meaning, some of which I have illustrated with Wierzbicka's explications and my amendments, but they are universally affectionate and loving.

Why do English speaking parents not use similar terms to address their children? The simple answer is that they do not exist in English. But the deeper question is why do they not exist? It is not that English lacks diminutives and baby talk altogether; there are onomatopoeic and sound-symbolic expressions like dindin, choo-choo, yum-yum, no-no, as well the suffix -y/-ie in tummy, blankie, doggie, etc. The form daughtery/ie is probably ruled out on phonological grounds, but sonny is well-formed, and exists, and yet is not used by parents.

I would like to argue that the absence of child-directed familial terms is due to the cultural value of individuality, as formulated in (2). As in the armed forces being addressed as private or soldier has the effect of making everyone the same, not discriminating among individuals, being addressed as son, daughter or child diminishes individuality and assigns a person to a particular class. It is also telling that while English lacks forms of familial address for children, there are in fact separate forms of formal address for children, such as Master, the honorific used for boys in letter addresses, whose very meaning suggests autonomy, freedom, and independence.

In contrast, Polish parents do not see the family as a training ground for individuality; they relish the fact that someone is their córka, syn, or dziecko and convey their love through the different forms of these words.

This value of individuality in American culture can be seen in naming practices as well. While Polish names are typically names of saints, or ancient coinages (Bogustaw, Bolesław, etc.) and are regulated by law, American first names are often simple nouns, such as Christian virtues (Faith, Hope, Charity), month names (April, May, June), flowers (Daisy, Rose), state names (Georgia, Virginia), last names (Washington, Jefferson), respellings (Lyndon for linden), and entirely made up words (Latisha) (Hock and Joseph 1996, pp. 308-312). The fact that Americans celebrate birthdays (which are unique), while Polish people celebrate namedays (which are shared with the people named for the same saint) is related to different religious traditions, but also underlines the differences in cultural values. 
So, what do American parents call their children? They use first names and their diminutives, nicknames, and terms of endearment (sweetie). Are these terms any less loving than córuś, synuś or dzieciatko? Not by a long shot. But they are for the most part unique, that is, individual. In this context what are we to make of kiddo? I am not sure, but I would like to think that American parents are in need of an appellation that is not unique and at the same time conveys closeness, love and the family ties that exists between them and their child.

The large amount of diminutives and address forms yield a very rich register of child-directed speech in Polish and Slavic, which is largely missing in English. Sun (2013) enumerates three cultural aspects that must be explicitly taught in a foreign language classroom: historical background, customs, and psychology. Forms of address fall into both the customs and psychology categories as they illuminate the underlying cultural values of warmth and inclusiveness in Polish and individuality and respect in English.

\section{REFERENCES}

Anstatt T., 2003, Der polnische Vokativ: Aussterbende Kasusform oder produktiv verwendetes Wortbildungsmittel?, "Zeitschrift für Slawistik" 50, pp. 328-347.

Fernald A., 1985, Four-month-old infants prefer to listen to motherese, "Infant Behavior and Development", no. 8(2), pp. 181-195.

Gleitman L. R., Newport E. L. and Gleitman H., 1984, The current status of the motherese hypothesis, "Journal of Child Language", no. 11, pp. 43-79.

Hall E. T., 1976, Beyond culture, New York.

Hock H. H., Joseph B. D., 1996, Language History, Language Change and Language Relationship: An Introduction to Historical and Comparative Linguistics, Berlin.

Markus H. R., Kitayama S., 1994, The Cultural Construction of Self and Emotion: Implications for Social Behavior, in: S. Kitayama, H. R. Markus (eds.), Emotion and Culture: Empirical Studies of Mutual Influence, Washington D.C., pp. 89-130.

Matychuk P., 2005, The role of child-directed speech in language acquisition: a case study, "Language Sciences", no. 27, pp. 301-379.

Nisbett R. E., 2003, The Geography of Thought: How Asians and Westerners Think Differently... and Why, New York.

Parrott L. A., 2010, Vocatives and Other Direct Address Forms: A Contrastive Study, in: A. Grønn, I. Marijanovic (eds.), Russian in Contrast, "Oslo Studies in Language”, no. 2, pp. 211-229.

Pyzik J., 2000, Przygoda z gramatyką: Fleksja i słowotwórstwo imion, Kraków.

Sun L., 2013, Culture teaching in foreign language teaching, "Theory and Practice in Language Studies", no. 3(2), pp. 371-375.

Szymczak M., 1966, Nazwy stopni pokrewieństwa i powinowactwa rodzinnego $w$ historii i dialektach języka polskiego, Warszawa.

Wierzbicka A., 1992, Semantics, Culture and Cognition: Universal Human Concepts in Culture-Specific Configurations, Oxford.

Wierzbicka A., 1999, Emotions Across Languages and Cultures: Diversity and Universals, Cambridge. 
Yokoyama O., 1994, Iconic manifestations of interlocutor distance in Russian, "Journal of Pragmatics", no. 22, pp. 83-102.

Zaleski J., 1963, Rozwój form wołacza żeńskich rzeczowników osobowych typu Marysia, Anulka, paniusia,"Onomastica”, no. 8, pp. 261-291.

\section{Corpora}

British National Corpus (BNC) http://www.natcorp.ox.ac.uk/

The Corpus of Contemporary American English (COCA) http://corpus.byu.edu/coca/ [28.08.2019].

Narodowy Korpus Języka Polskiego (NKJP) http://nkjp.uni.lodz.pl/index.jsp [28.08.2019].

Katarzyna Dziwirek

\section{JAK MÓWIMY DO DZIECI? FAMILIJNE FORMULY ADRESATYWNE W JĘZYKU POLSKIM I ANGIELSKIM}

Słowa kluczowe: formuły adresatywne, dzieci, kulturowe scenariusze, kolektywizm, indywidualizm, nauczanie języka polskiego jako obcego

Streszczenie. Przekaz kulturowy w glottodydaktyce przejawia się nie tylko w transmisji wiedzy o tradycjach, zwyczajach czy historii danego kraju, ale również w uwrażliwieniu studentów na podstawowe idee i zachowania obcej kultury. Obecny artykuł przedstawia zasadnicze kontrasty między polską i angielskojęzyczną kulturą i ich wpływ na język używany w gronie rodziny. Polscy rodzice często używają zdrobnień familijnych terminów syn, córka czy dziecko, co nigdy nie zdarza się w angielskojęzycznych rodzinach. Artykuł pokazuje, że te różnice wypływają z różnic kulturowych. Kultura polska jest kulturą kolektywistyczną i jedną z jej podstawowych wartości jest serdeczność. Kultura anglojęzyczna jest kulturą indywidualistyczną, w której niezależność jej naczelną wartością. 